\title{
STRENGTHENING CHARACTER EDUCATION IN ELEMENTARY SCHOOL WITH INTERNATIONAL CURRICULUM \\ (A Case Study at Bestari Utami Elementary School, Garut)
}

\author{
Santi Susanti and Sukaesih \\ Faculty of Communication Sciences, Universitas Padjadjaran, \\ Jl. Raya Bandung-Sumedang Km. 21 Jatinangor, 456363 \\ E-mail: santi.susanti@unpad.ac.id; sukaesih@unpad.ac.id
}

\begin{abstract}
Character education is necessary given to children from an early age, to manage their emotions and become individuals who have positive behavior for themselves and their surrounding environment in the future. The implication of good character education will make children do things consciously, committed, and competent, and grow into social beings who help each other, civilized and polite. This research aims to reveal the strengthening of character education for students at Bestari Utami elementary school in Garut. This school applies an entrepreneurial curriculum with international school learning methods, but still concerning character education to students based on the local cultural wisdom of Sundanese. This research uses a qualitative method with a case study approach. The primary data obtained through in-depth interviews with school managers and observations of learning activities at SD Bestari Utami. Secondary data obtained through literature and document reviews relevant to the research. Data analysis using interactive data analysis models from Miles and Huberman. The results showed that character education at SD Bestari Utami refers to equality and unity as a fundamental concept of school education. Children deserve to get quality education regardless of their ethnic, religion, and economic background. Strengthening character values based on Pancasila that comprises religious values, nationalism, independence, integrity, and cooperation are embodied through cultural arts lessons that are included in the school curriculum, as well as implementing learning that motivates children to be independent and able to work together with their friends. This study concludes that character education will be effective and give an impact if applied to students and school managers.
\end{abstract}

Keywords: character education; elementary school; art \& culture; curriculum; bestari utami

\section{PENDIDIKAN KARAKTER DI SEKOLAH DASAR BERKURIKULUM INTERNASIONAL DI GARUT, JAWA BARAT (Studi Kasus di SD Bestari Utami, Garut)}

\begin{abstract}
ABSTRAK. Pendidikan karakter sangat penting diberikan kepada anak-anak sejak dini, agar mereka memiliki kemampuan untuk mengelola emosinya dan menjadi pribadi yang berperilaku positif pada diri dan lingkungan sekitarnya di masa mendatang. Implikasinya, pendidikan karakter yang baik akan membuat anak-anak melakukan hal dengan sadar, berkomitmen, dan kompeten, serta tumbuh menjadi makhluk sosial yang saling membantu, beradab dan sopan santun. Penelitian ini bertujuan untuk mengungkap penguatan pendidikan karakter bagi anak didik di sekolah dasar Bestari Utami di Garut. Sekolah ini menerapkan kurikulum kewirausahaan dengan metode pembelajaran sekolah internasional, namun tetap memerhatikan pendidikan karakter kepada anak-anak didiknya berdasarkan kearifan lokal budaya Sunda di lingkungan wilayah tempat mereka tinggal. Penelitian ini menggunakan metode penelitian kualitatifdengan pendekatan studi kasus. Data primer diperoleh melalui wawancara mendalam kepada pengelola sekolah dan observasi partisipatif kegiatan pembelajaran di SD Bestari Utami. Data sekunder diperoleh melalui kajian pustaka dan dokumen yang relevan dengan penelitian. Analisis data menggunakan model data interaktif dari Miles dan Huberman. Hasil penelitian menunjukkan, pendidikan karakter di SD Bestari Utami mengacu pada konsep utama pendidikan sekolah, yakni kesetaraan dan kebersamaan. Semua anak berhak mendapatkan pendidikan berkualitas tanpa membedakan latar belakang suku, agama dan tingkat ekonomi keluarga mereka. Penguatan nilai karakter berdasarkan Pancasila yang terdiri dari karakter religius, nasionalis, mandiri, integritas dan gotong royong ditanamkan melalui pelajaran seni budaya yang dimasukkan ke dalam kurikulum sekolah, serta menerapkan pembelajaran yang mendorong anak untuk mandiri juga mampu bekerja sama dengan teman-temannya. Hasil penelitian menyimpulkan, pendidikan karakter akan berlangsung efektif dan memberikan dampak pada peserta didik, jika diterapkan secara menyeluruh kepada peserta didik maupun pengelola sekolah.
\end{abstract}

Kata kunci: pendidikan karakter; sekolah dasar; seni budaya; kurikulum; bestari utami

\section{INTRODUCTION}

The Ministry of National Education strategic plan of 2010-2014 direct education not only to develop cognition, affection and psychomotor aspects, but also to shape students into individuals who have moral character in living their lives.
It indicates that character education is needed to produce students who have moral character, which will have a positive impact on themselves and the students' environment.

Character education is needed because the quality of attitudes and morals of children or the younger generation has been decreased. The curriculum of 
character education needed in the sense that the curriculum itself has character and at the same time it is oriented in shaping the character of students " (Rohman 2012).

As described by Zuhdi (2009, p. 39-40), there are seven moral crises occurring among the people of Indonesia at this time including the crisis of honesty, responsibility, discipline, justice, togetherness crisis and inability to think wisely.

This condition is allegedly resulted by education where demoralization happens because the learning process tends to focus the moral and charactereducation only on textual level without preparing the students with skills to face challenges and contradictions in life. The existing crisis and moral decadence indicate that all religious and moral knowledge acquired in school do not have an impact on the change of human behavior in Indonesia. Even worse, many the Indonesians tend to be hypocrite where they do not do what they say or say what they do.

As described by Koesoema in Zubaedi (2012, p. 3): 'the society's and government's commitment to integrate education and character building are the weak points of the national education system. Therefore, all parties should agree to work together in tackling this moral decadence. Doctors, policy makers, religious leaders, entrepreneurs, educators, parents and society, all have the same concern about this conditions. We do have to worry because shocking tragedy and statistics regarding crisis in the youth are everywhere in the news. Therefore, we must strive to find solutions to these problems.

Instead of being addressed as moral education that involves realized and actual virtues, the process of character education prioritizes the process of the value and attitude internalization to develop good characters. The values in this sense are the ones that help people to learn to leave together. They are related to various aspects of life such as people's relationships, personal life (learning to be), statehood, worldly life, and the preparation of afterlife.

The intentional teaching of moral character is particularly important in today's society since our youth face many opportunities and dangers unknown to earlier generations. They are bombarded with many more negative influences through the media and other external sources prevalent in today's culture. Formal education in Indonesia commonly focuses on intellectual or cognitive development, while the soft skills or nonacademic aspects as the major elements of character education have not been considered optimally and even tend to be ignored. (Zubaedi 2012).

Character is a personality trait of a person who is closely related to the overall values he has.
Character building starts from the family covering spiritual, emotional, intellectual and moral aspects.

Character education defined as the education of values, ethics, character, which develop the ability of students to make good and bad decisions, maintain what is good and creates goodness in everyday life wholeheartedly. The psychological content of character education includes moral dimensions, reasoning, moral feeling and moral behavior (Lickona 1991). The combination of cognitive and soft skills is a competitive capital for individuals to be able to survive in the flow of changes that come so fast.

Character education has the following objectives as follows: (1) developing the potential of the heart/conscience/ affective of students as humans and citizens who have national character values, (2) developing habits and behavior of students that are commendable and in line with universal values and religious-national cultural traditions, (3) instilling a spirit of leadership and responsibility of students as the next generation of the nation, (4) developing the ability of students to become independent, creative, and nationally minded humans, and (5) developing the school life environment as a learning environment that is safe, honest, full of creativity and friendship, and with a high sense of nationality and full of strength (Zubaedi 2012). Characteristics of a person's personality, especially students, are not something that cannot be changed because these changes are also supported by interactions with other people and the influence of the surrounding environment.

Thomas Lickona defines seven reasons why character education should be given to citizens from an early age, as follows:

- Character education is the best way to ensure students have a good personality and character in life.

- Character education can help improve students' academic achievement.

- Some children cannot form strong characters for themselves in other places.

- Character education can form individuals who appreciate and respect others and can live in a pluralistic society.

- To overcome the root of moral-social problems, such as dishonesty, immodesty, violence, low work ethic, and others.

- Is the best way to shape individual behavior before entering the world of work/business.

- As a way to teach cultural values, which are part of the work of a civilization.

The education success begins with the success of an active and creative learning process. In formal 
education, character education material is contained in each subject and local content. The concept of character education has long been echoed to make the younger generation the nation's successor.

Zubaedi states that character education is an effort to educate in thinking, appreciating attitudes and practices in the form of behavior in accordance with the values that become the national identity (Zubaedi 2012). The implementation of a supportive curriculum and educators who have a strong vision to realize a quality educational character is critical in realizing the character of education in schools.

Character education in learning is expected to be able to make changes to the attitudes, behavior, skills and abilities of students in the field they are engaged in. Additionally, character education can be part of moral formation process of the nation's children and can become the main foundation in increasing the degree and dignity of the Indonesian nation. Education could be a guidance tool for students to become human beings with behavior and have moral character, and strong nationalism (Manurung 2011)

Indonesia's government issued Presidential Regulation Number 87 of 2017 concerning Strengthening Character Education, one of which build and equip students as the golden generation of Indonesia in 2045 with the spirit of Pancasila and moral character education to face the dynamics of change in the future". The five main values of the priority characters of Strengthening Character Education that come from Pancasila consist of, 1) Religious; Reflects belief in God Almighty. 2) Nationalist; Placing the interests of the nation and state above the interests of themselves and their groups; is a way of thinking, behaving and acting that shows loyalty, concern and respect for the nation's language, environment, social, culture and politics. 3) Independent; Do not depend on other people and use energy, thoughts, time to realize hopes, dreams and ideals; 4) Gotong royong; reflects the action of respecting the spirit of cooperation and working hand in hand to solve common problems; 5) Integrity; is a value that forms the basis of every individual's behavior by which the individual could be trusted in words and deeds, and is committed to moral and human values (Kemdikbud.go.id 2017).

Character education is conducted with a direct approach to students by instilling moral values and providing lessons on moral knowledge to students to prevent them from engaging in prohibited behavior, which can endanger themselves and others (Santrock 2012).

The school environment is one part that affects the learning process. The school environment affects the personal development and achievement of students. School is a strategic place to foster a love for the nation's culture, as well as a vehicle for character building for each individual to shape himself as a mature and responsible citizen. Equipping students with the spirit of Pancasila in the present is a challenge that educators should face.

Bestari Utami Elementary School is a private school in the District of Garut Kota, West Java, founded in 2009 with the principles of equality and togetherness. Students are taught to respect differences and promote togetherness, even though they have different ethnic, economic, and religious backgrounds.

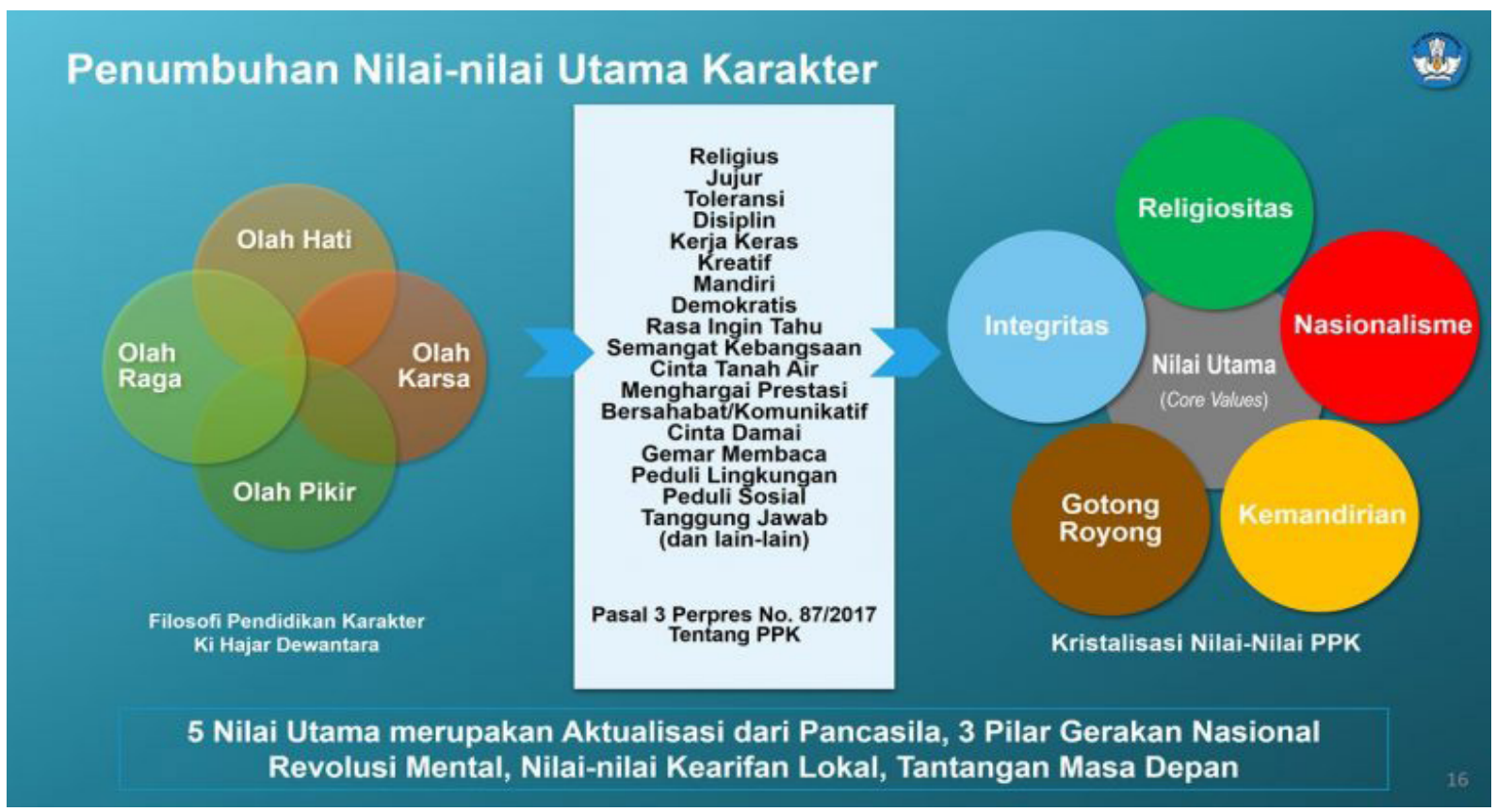

Figure 1. Main Values of Character Derived from Pancasila

Source: Kemdikbud, 2017

Strengthening Character Education in Elementary School with International Curriculum

(A Case Study at Bestari Utami Elementary School, Garut)

(Santi Susanti and Sukaesih) 
Bestari Utami Elementary School students combine Chinese and non-Chinese descent, with a composition of $20 \%$ Chinese and $80 \%$ non-Chinese. This combination made as a form of appreciation for the Sundanese people in Garut who have provided valuable lessons to the founders of the school and their families about the meaning of togetherness without questioning the differences between them.

The cultivation of character education for children has been applied in formal and informal schools, generally through cultural arts. For example, the application of character education to elementary school students through dance designed by Dedi Rosala (2016). Based on his literature review, Dedi shows that character education through dance education is reflected in tolerance, solidarity and togetherness (Rosala 2016).

The application of character education to children in an informal school environment carried out by the Hong Community. In her research entitled Internalization of Character Education Values through Kakawihan Kaulinan Barudak Buhun in the Hong Community, Mayakania (2013), shows that children's play accompanied by singing can foster children's character into individual personalities. Internalization of educational values in Kakawihan Kaulinan Barudak Buhun is conducted through habituation, which rests on 3 components, namely knowing nature, culture and God (Mayakania 2013).

Azis, Komalasariand Masyitoh(2020), research about Strengthening young generation characters in the disruption era through the internalization of wayang golek values. The results showed that the values of Wayang Golek performances contribute to strengthening the character of younger generation, because the puppet show is designed as an art performance that contains elements of the spectacle as well as guidance. This means, in addition to entertaining through humorous jokes, the Wayang Golek performance is able to give a moral message to the audience about the importance of religious values and nationalism despite changing times (Azis, Komalasari, and Masyitoh, 2020).

Harnani, Amijaya and Setiadiwibawa (2020) researched creative entrepreneurship-learning models to foster student creativity and innovation. Using quantitative research methods, the results show that creative entrepreneurship learning affect the creativity and innovation of Winaya Mukti University students (Harnani, 2020).

This research was conducted in schools that apply an international standard curriculum, but do not eliminate the roots of local Sundanese culture. The character education applied in this school upholds the principles of equality and togetherness. All students have the same opportunity to get quality education regardless of their life background.

Some studies that the authors found, most of the focus of their research still places character education as extracurricular activities. In this study, the subjects studied were schools that had implemented character education as part of the curriculum in their schools.

This study reveals the pattern of education at the Bestari Utami Elementary School in instilling the priority values of Character Education in students based on local cultural values. Local colors reflect the nation of Indonesia (Manurung 2011). The emphasis of the discussion is on the five main values of the priority characters of Strengthening Character Education set by the Ministry of Education and Culture of the Republic of Indonesia, namely religious, nationalist, independent, mutual cooperation and integrity values, based on the character education philosophy of $\mathrm{Ki}$ Hadjar Dewantara which consists of heart (ethics), taste (aesthetic), thought (literacy), exercise (kinesthetic). Cultivation of the heart is related to deep spirituality, faith and piety. Cultivating feelings related to moral integrity, a sense of art and culture. Mindfulness is related to academic excellence because of lifelong learning and learning. Exercise is related to health and being able to actively participate as citizens.

\section{METHOD}

This study uses a qualitative descriptive method with a case study approach to explore information about character education at SD Bestari Utami, Garut. According to Yin (2011), what will be investigated in case studies are phenomena in real-life contexts, because the boundaries between phenomena and contexts are not clearly visible so that multiple sources of evidence are used.

Data collection were obtained through indepth interviews, non-participatory observation, and document review, and various information relevant to the research subject. Interviews were conducted with the school founder, Christanti Gomulia, as well as 4 teachers, to get information about the experiences of teachers in instilling character education in the students of Bestari Utami School, Garut. Nonparticipatory observation is conducted by observing teaching activities at Bestari Utami School, which are academic and artistic, conducted inside and outside the classroom which is related to the character-building of students in schools. Data analysis went through four continuous stages during the research process to produce data descriptions and conclusions. 


\section{RESULTS AND DISCUSSION}

\section{Bestari Utami School at a Glance}

Moral character is not formed automatically; it is developed over time through a sustained process of teaching, example, learning and practice. It is developed through character education (Pala, 2011). The implementation of character education at Bestari Utami School is related to the life experiences of its founder, Christanti Gomulia, a Chinese woman who has a great interest in education, especially children's education. Tanti, since she was born, lived among Sundanese neighborhood in Jalan Pasundan, Garut, which had differences in ethnicity, economic, and religious terms with her family. However, Tanti and her family did not get different treatment from their neighbor in their daily interactions. Their mutual respect remains in Tanti's self and mind until adulthood.

Her childhood experiences strengthen while pursuing an Undergraduate Degree at the University of Sanatadarma Yogyakarta and a Master's Degree at the University of Bath, England. Interactions with her friends at the university proved that respecting each other's differences is an exquisite. They live peacefully and comfortably in conducting daily activities at school and introduce their respective arts and culture.

Feeling how beautiful living in harmony with a diversity of people reinforces Tanti's to make her idealism comes true in establishing a school that is open to anyone regardless of ethnic, religious, and economic background. Tanti's dreams want to restore basic education as a 'school of life', which developed children in terms of concept, life skills, and character until she founded a school that respects difference.

Tanti made the school an accessible place for all groups of society. As a public space, the school is a place without the shackles of power. Students and teachers can interact without barriers (Martono et al., 2019).

Along with her husband, in 2009, Tanti established the Bestari Utami Elementary School, an international paradigm school with 'affordable' fees, even free for underprivileged children and teachers in Garut. The school that applies the Ciputra Entrepreneurship Education Way learning model is the only Entrepreneurship School with a National Curriculum in Garut that brings students to be innovative, productive, and creative individuals from an early age.

Following her dreams, Tanti established a school for anyone and eliminate the differences between the Sundanese as "pribumi" and the Chinese as "immigrants". The students' composition is set at
80 percent for the majority group and 20 percent for the minority. This school is expected to be a medium of assimilation for Garut residents, so there is no more group blockage or stigma (Bestariutami, 2011).

Thematic learning patterns and principles of fun education provide children the space to explore themselves and apply the right thematic learning to real projects they are working on. The treatment made children become active and happy to ask and question everything.

Bestari Utami School's education is directed toward the formation of $3 \mathrm{H}$ (Head, Hands, and Heart), which means the creation of balanced students in concepts, life skills, and children's character. Thus, children are not only good academically, but are willing to learn and study new things with enthusiasm.

The idealism that Bestari Utami school wants to achieve is 1) returns parents' role as real educators, by eliminating additional lessons at school; 2) return the role of children as learners who need appreciation for personal uniqueness and are not based on rigid and uniform evaluation standards, by becoming a school that provides assessments to children not only rely on academic abilities; 3 ) return children to their roots with the mission to think globally, act locally, by become a school that produces graduates who are ready to face the demands of globalization, but still respecting eastern values 4) become a school that purely educates and does not do business with children by avoiding seeking profit, but prioritizing quality and sincerely building the next generation.; 5) restoring the idealism and positive image of teachers who "love children" by developing team teaching and "teachers who care for children" by becoming schools that make teachers become individuals who are "fond" of discussing fun ways of teaching for children; 6) restoring the objectives of education which in essence are not only reserved for a certain group of people, by becoming a school that accepts students regardless of racial background (Bestariutami, 2011).

Bestari Utami can be categorized as a school that applies a multicultural education to students. Multiculturalism education has the following characteristics: (1) aim to form a "cultural human" and create a "cultured (civilized) society", (2) the material teaches noble values of humanity, national values, and ethnic groups values (cultural), (3) democratic that respects the differences and cultural diversity of the nation and ethnic groups (multiculturalists), (4) the evaluation is determined on the assessment of students behavioral, which includes perception, appreciation, and action towards 
other cultures (Maksum and Ruhendy, 2009)

Dede Gusnadi, homeroom teacher for grade 3 at SDN Bestari Utami explained, to build closeness with his students, he puts himself as a friend to his students. "As a teacher, they seem a little shy. As a friend, they feel close. Approaching them is even easier."

\section{Strengthening the Values of Religious Character}

Religious values are related to the belief in Almighty God, who is personal and a basic right of every individual. Religious values imply norms of goodness that prioritize moral values with mutual respect and peaceful togetherness.

Religious values at SD Bestari Utami are maintained with the principle of mutual respect among followers of different religions, and provide opportunities to worship according to their respective beliefs. Strengthening religious values is conducted through building the character of goodness in each child by conveying universal moral stories or stories of goodness. Religious subject matter is given to students according to their respective religions. For Moslem children, they are taught Iqro and provided a place to pray.

The embedding of moral and religious character for students at SD Bestari Utami conducted by prohibiting bullying, in both physical and verbal forms. The prohibition of bullying is conveyed verbally and written, posted on the classroom walls. It contains the prohibition of bullying and the provision of punishment for violators.

\section{Strengthening Nationalist Character Values}

Nationalist character values are a way of thinking, behaving and acting for expressing loyalty, concern, and respect for the nation's language, environment, social, culture and politics. The implementation of nationalist character values in people's daily lives can be seen in several ways, including an appreciation of Indonesian culture, taking care of Indonesia's cultural wealth, spirit of nationalism, and respect for cultural, ethnic and religious diversity.

Education leader and founder of the School of Taman Siswa, Ki Hadjar Dewantara, stated that character education can be achieved through art and culture. Ki Hadjar believes that art and culture are the most fundamental parts of student character education. Haidar Musyafa, in his book Ki Hadjar Dewantara: A Memoir, writes "If a nation wants to grow into a healthy nation physically and mentally, the education and teaching system given to the people based on national cultural principles, and culture in its own society." (Ardanareswari, 2019).
Local cultural arts are a way that is considered effective in instilling the main values of character to learners. Art lessons are given to provide an aesthetic experience as well as instilling values or meanings of life that contain universal values of individual characters.

Sundanese local culture-based education is an important educational process in the school system in West Java. By knowing the local culture, one can appreciate the differences that occur in the community and to become an Indonesian citizen or a citizen of the world, one does not have to abandon the values of local culture.

Banks explained that in the early stages, students need to be introduced to their cultural values before cultural values outside the community. In the next stage, children are introduced to the global cultural value order. This process is necessary to prevent the younger generation lose their cultural identity when making contact with people outside their ethnic group (Banks 1986).

Sundanese local culture-based education is an important educational process in the school system in West Java, so that children know the culture and can appreciate the differences in customs in society. One does not need to leave the original cultural values to become a citizen of the world (Hermawan, 2012)

The principle of respecting local culture, applied the beginning of the school's establishment. Students of SD Bestari Utami, regardless of background, can obtain good quality education without losing the local cultural identity of the people in their neighborhood, namely, Sundanese culture. The Implementation of this principle was based on Tanti's experience while studying a master's degree in Education Management at the University of Bath, England. On the student's night, Tanti received a standing ovation from her fellow students after she finished singing traditional Sundanese songs, Bubuy Bulan and Bongan Bangkong, through a long time practicing.

Tanti's experiences open her insight that culture is the nation's treasure that can still be proud of and preserve because it contains a local wisdom reflecting the positive moral values character of the Indonesian. It agrees with Julia's research, which shows that local arts education can change the behavior or characteristics of students. In traditional art, there is a local wisdom whose value is universal (Julia, 2012).

Tanti wants her students to know and apply local wisdom in their life. Tanti incorporates art and culture subjects into the curriculum of SD Bestari Utami, not as an extracurricular activity, so that all her students can learn art, as part of affective 
development process. The arts taught at Bestari Utami School are Gamelan, Dance, and children's traditional games.

Incorporating art and culture lessons into the curriculum, forcing students to engage in cultural arts activities. Hopefully, children become accustomed and will grow a love for their own culture. This condition is different from the results of Sarah Atikah Tsamarah's research on nationalism value education at SD Negeri 2 Wates Kulon Progo (2016). The results of her research showed that the value of nationalism education was obtained through habituation and exemplary encountered obstacles in student involvement in batik learning because, it was placed as an extracurricular lesson.

Gamelan is a local cultural arts given to students of Bestari Utama grades three through sixth grade. Meanwhile, children in the first to second grade were given Sundanese songs and dances, in the form of theory and direct practice by the students.

Tanti explains, valuable lessons that learned by students of Bestari Utami while teaching gamelan are related to the formation of children's emotions when they first learn to be proficient in playing them. When playing gamelan, every child learns to work together, diligently, persistence in learning it, is patient in controlling their emotions. Focus on playing by playing wholeheartedly so that the sound of the musical instrument played is in harmony and easy to hear. The ability of students in processing the feeling of being sharpened when playing gamelan so that their emotions and behaviors become more controlled. Students are finally master themselves well to be able to play gamelan with a rhythm that is good to hear.

Learning gamelan has two impacts, long-term and short-term impacts. The long-term impact, in the form of emotional control, will be felt in students lives as they grow up. Meanwhile, the short-term impact will be seen from the improvement in children's emotions when playing gamelan.

This condition shows that music functions as a physical response, which is a counterweight to the condition in a person who is experiencing disturbances. Music and sound can improve the disturbances that occur in individuals in relation to humans and with nature (Djohan, 2006).

In 2011, SD Bestari Utami performed a musical drama involving all students at the school. The performance is entitled Kabayan the City Boy, which is packaged by combining Sundanese traditional music and dialog in English. All students who participated in the training were involved in showing the beauty of being together in diversity. The students of SD Bestari Utami mingle and enjoy the togetherness without hindered by the differences between them. In this performance, music acts as a medium of integration, which unites children in one condition that creates a sense of togetherness in their hearts and the audience. Tanti understands, learning music cannot internalize its students as a whole because external influences such as K-Pop music are compelling. However, she hopes that, in the next few years, the lessons learned by the child at this time, will be realized and internalized in them to love the art of Indonesian culture.

\section{Implementation of Independent Character Value}

Bestari Utami is a school with an entrepreneurial concept. Every student encouraged to be a creative figure in creating business opportunities and being able to work independently and solve problems at hand. One of the efforts made to create business opportunities is to re-explore traditional culinary delights with the guidance of teachers. To become an entrepreneur, the characters that are built include perseverance, never giving up, being creative and clever in managing time and being independent.

Independent character is developed through the process of working on individual tasks. Each student starting in grade 4 is accustomed to doing assignments independently from the process to the final result. They are also accustomed to being able to openly express their opinions in front of the class.

The results of strengthening the independent character can be seen when students send videos while doing assignments given by their teachers online in online learning during the COVID-19 pandemic. They also dare to speak in front of the class, express opinions freely, to answer questions from their teachers.

\section{Implementation of Integrity Character Value}

The character value of integrity is the basis of behavior that makes individual words and deeds trustworthy, and committed to the morals and values of humanity. The application of the value of integrity character in everyday people's lives can be seen from the attitude of responsibility, actively involved in social life and consistent in words and deeds based on the truth.

It's not easy to believe in what you are saying and what you are doing. Many of the obstacles come from the self and the internal environment. Tanti stated that character education in Indonesia failed because the figure was not true, their speech and actions were not aligned.

Bestari Utami embodies the formation of strong character in the school not only to the 
students, but also to the teachers and all school managers. The teachers who have strong characters will be memorized dan touched their students. The school provides training to prospective teachers to equate the perception of integrity and the teaching patterns. Christanti directly gave the training. She is experienced as a lecturer in Bandung and received a master of education management at the University of Bath, England. Evaluations are held weekly to assess the quality of learning during the week to stay consistent and improved.

A violation of school regulations, resulting in the implementation of punishment. Tanti was once forced to expel her school staff, for being dishonest in her financial problems. Tanti cannot tolerate dishonesty. Strict discipline is applied to teachers and students in her school.

"Despite the fact that its hard and stressful, I had to fire dishonest teachers and staff. Because from the very beginning of establishing the school, we are committed to taking nothing away from the children. Sustenance will be there, but not from children."

\section{Implementation of Gotong Royong Character Value}

The value of gotong royong (mutual cooperation) character is an attitude and behavior that appreciates the spirit of cooperation and shoulder to shoulder in solving problems together. The value of mutual character can be implemented into the behavior of respecting others, working together, committing to mutual decisions, mutual help, solidarity and volunteerism, anti-discrimination and nonviolence.

Embedding the value of gotong royong character in SD Bestari Utami is conducted through academic and nonacademic activities. Embedding the value of the character gotong royong academically, conducted in the work of group assignment projects from the homeroom teacher, for example, culinary activities. During the project, each member of the group worked on their part in processing food, with guidance from the homeroom teacher. After finish cooking, they present the food.

In the nonacademic sphere, the character of gotong royong instilled in social activities makes a flea market for the poor meet the needs ahead of Eid al-Fitr. The proceeds from the flea market are used to buy gamelan and others. The children make their own procurement of gamelan through their mutual activities.

The internalization of social care value is urgent for teachers in elementary schools to form the character of students (Masrukhan, 2016). The internalization can be achieved through activities or learning. The character of students needs to be built as the strength of individuals who become the successor of the family and society (Jalil, 2012).

Social activities are an effort in embedding character education to students. Students learn to work together while fostering social care in the surrounding conditions.

\section{CONCLUSION}

Strengthening character education at Bestari Utami Elementary School is conducted by referring to the concept of togetherness and equality established since the beginning of the school's establishment, as well as making local cultural arts part of the curriculum, not as extracurricular activities so that all students get it. Through cultural arts, the students were successfully united and the dividers of differences between students were successfully merged. The students of SD Bestari Utami can interact without being awkward and succeed in realizing a small Indonesia, which implements character education with religious values, nationalism, integrity, independence and mutual cooperation.

\section{REFERENCES}

Ardanareswari, I. (2019). Pendidikan Karakter Ki Hadjar: Lewat Kesenian, Bukan Baris Berbaris. Retrieved January 7, 2020 (https:// tirto.id/pendidikan-karakter-ki-hadjar-lewatkesenian-bukan-baris-berbaris-edxJ).

Azis, A., Komalasari, K. \& Masyitoh, I.I. (2020). Strengthening Young Generation Characters in the Disruption Era Through the Internalization of Wayang Golek Values. Sosiohumaniora 22(3) ,356. doi: 10.24198/sosiohumaniora. v22i3.26162.

Banks, J.A. (1986). Teaching Strategies for Ethnic Studies. Fourth. Boston: Allyn and Bacon, Inc.

Bestariutami.(2011). Peduli Untuk Sekolah Idealis Di Kota Kecil Garut. Retrieved January 7, 2021 (http://bestariutami.blogspot.com/2011/08/ blog-post_12.html).

Djohan. (2006). Terapi Musik. Yogyakarta: Galang Press.

Harnani, N. (2020). Model Pembelajaran Kewirausahaan Kreatif Melalui Praktek Usaha Dalam Menumbuhkan Kreatifitas Dan Inovatif Mahasiswa (Studi Pada Mahasiswa 
Manajemen Di Fakultas Ekonomi Bisnis Universitas Winaya Mukti Kota Bandung). Sosiohumaniora 22(1), 79-87. doi: 10.24198/ sosiohumaniora.v22i1.24510.

Hermawan, I. (2012). Kearifan Lokal Sunda Dalam Pendidikan. Widyariset 15(1), 29-37.

Jalil, A. (2012). Karakter Pendidikan Untuk Membentuk Pendidikan Karakter. Jurnal Pendidikan Islam 6(2), 175-192.

Julia. (2012). Membentuk Keindahan Moral Melalui Pendidikan Seni Berbasis Tradisi Lokal. in Seminar Nasional Quo Vadis Seni Tradisional 7. Bandung.

Kemdikbud.go.id. (2017). Penguatan Pendidikan Karakter Jadi Pintu Masuk Pembenahan Pendidikan Nasional. Retrieved December 28, $2020 \quad$ (https://www.kemdikbud.go.id/ main/blog/2017/07/penguatan-pendidikankarakter-jadi-pintu-masuk-pembenahanpendidikan-nasional).

Lickona, T. (1991). Educating for Character: How Our Schools Can Teach Respect and Responsibility. New York: Bantam.

Maksum, A., \& Ruhendy, L.Y. (2009). Paradigma Pendidikan Universal. Yogyakarta: IRCSod.

Manurung, R.T. (2011). Pengajaran Bahasa Yang Berkarakter Kebangsaan Dan Berperspektif Multibudaya Dalam Era Globalisasi. Sosiohumaniora 13(2), 235-42. doi: 10.24198/sosiohumaniora.v13i2.5519.

Martono, N., Mintarti, E.P, \& Sulyana, D. (2019). Sekolah Inklusi Sebagai Arena Kekerasan Simbolik. Sosiohumaniora 21(2), 150-58. doi: 10.24198/sosiohumaniora.v21i2.18557.
Masrukhan, A. (2016). Pelaksanaan Pendidikan Karakter Peduli Sosial Di SD Negeri Kotagede 5 Yogyakarta. Basic Education, Jurnal Pendidikan Guru Sekolah Dasar 5(29). 2.182-2.820.

Mayakania, N.D. (2013). Internalisasi Nilai-Nilai Pendidikan Karakter Melalui Kakawihan Kaulinan Barudak Buhun Di Komunitas 'Hong' Bandung. Panggung 23(4), 443-55.

Pala, A. (2011). The Need for Character Education. International Journal of Social Sciences and Humanity Studies 3(2), 23-32.

Rohman, M. (2012). Kurikulum Berkarakter. Jakarta: Prestasi Pustakaraya.

Rosala, D. (2016). Pembelajaran Seni Budaya Berbasis Kearifan Lokal Dalam Upaya Membangun Pendidikan Karakter Siswa Di Sekolah Dasar. Ritme Jurnal Seni Dan Desain Serta Pembelajarannya 2(1), 17-26.

Santrock, J.W. (2012). Educational Psychology. 3rd ed. Jakarta: Salemba Humanika.

Yin, R.K. (2011). Case Study Research: Design and Methods (Applied Social Research Methods). Illinois: Sage Publication.

Zubaedi. (2012). Desain Pendidikan Karakter, Konsepsi Dan Aplikasinya Dalam Lembaga Pendidikan. Jakarta: Kencana Prenada Media Group. 